\title{
Europeanization, Religion and Collective Identities in an Enlarging
}

Europe

\section{A Multiple Modernities Perspective}

\author{
Willfried Spohn
}

FREE UNIVERSITY OF BERLIN AND UNIVERSITY OF GÖTTINGEN

\begin{abstract}
This article analyzes the conflictive role of religion in post-1989 Europe. Three major reasons for this are addressed: first, the restoration of structural and cultural pluralism of European civilization since the breakdown of communism entails the reconstitution of the full diversity of European religion. Second, international migration as a crucial part of globalization has intensified, contributing to the transformation of Europe into a complex of multi-cultural and pluri-religious societies. Third, the wave of contemporary globalization has been accompanied by an intensification of inter-civilizational and interreligious encounters and conflicts - particularly between Christianity and Islam. As a result, European integration and enlargement as a secular and humanist mode of cultural integration and religious governance are basically challenged by this three-fold revitalization of religion. The growing tendency is to respond to this challenge by enhancing the Christian foundations of Europe rather than, as this article argues, to follow a more cosmopolitan, secularist and religious pluralist mode of European cultural integration.
\end{abstract}

\section{Key words}

- cultural integration - Europeanization — modernities — religions

In post-1989 Europe, religion is playing a growing and increasingly conflictive role in European societies and politics. There are three interrelated reasons for this: first, along with the breakdown of communism and the reconnection of divided Europe, there has re-emerged the encompassing structural and cultural pluralism of European civilization characterized by different forms of religion and secularization patterns, as well as their varying impacts on states, nations, ethnic groups and related collective identities. Second, European societies have been transformed, due to the impact of growing international migration and immigration, into more multi-cultural and religiously more diversified societies. 
Third, the wave of contemporary globalization has been accompanied by an intensification of inter-civilizational and inter-religious encounters in cooperative and competitive as well as, particularly between the Islamic world and the Christiansecularized West, in markedly conflictive ways. All three factors - the religious diversity of Europe, the multi-religious composition of European societies and the inter-civilizational interactions of religion - also existed before 1989, but through the breakdown of communism they have gained considerably more weight and increasing potential for conflict in an enlarging Europe.

As a consequence of the revival of religion, the enlarging European integration of the East and the South-East, motivated by the vision of an encompassing pan-European political-legal and economic transnational order, and based on a humanist-secularist and Christian-ecumenical mode of European cultural integration and European identity, is increasingly running into difficulties. On the one hand, there are structural and institutional problems of politico-legally and socio-economically integrating a large number of new nation-states with respective repercussions on the old member states and the transnational European framework. On the other, the secular-ecumenical cultural integration mode of the EU is being challenged by the growing impact of other, different and less secularized religions within European societies and beyond. This multifaceted legitimacy crisis of an enlarging Europe erupted in the public rejection of the pending European constitutional contract - in many ways functional to overcome the institutional and political impasses of the eastern enlargement but contested in its inability to reconcile the different religious and secular legacies in the current and prospective member states. As a consequence, both the immigration and integration policy of ethnic minorities as well as the eastern enlargement of the European Union have become more restrictive and exclusive.

In view of the growing and increasingly conflictive role of religion in Europe, not only the predominant European secularist-cultural integration mode but also the predominant approaches in the social and political sciences have until recently been rather ill-equipped to provide an analysis, explanation and potential redirection of the cultural dimensions of European integration policy. Most analyses of European integration, in tune with the predominant modernizationcum-secularization thesis, still omit the issue of religion. Only recently has a new research interest in Europeanization and religion been developing.

In this context, I will do the following: (1) outline the multiple modernities approach to Europeanization and religion; (2) compare the different relationships of the religious-secular configurations in Western and Eastern Europe to the EU cultural integration mode; (3) characterize European and national forms of citizenship and cultural integration regarding immigrants and their minority religions; (4) analyze the growing impact of religious diversity and mobilization on European intra- and inter-civilizational boundary constructions and the consequences for the eastern enlargement of the European Union; and (5) conclude with a critique of the secular-religious European cultural integration mode from the perspective of a (North American) mode of religious pluralism. 


\section{Europeanization, Religion and Collective Identities - a Multiple Modernities Approach}

Theories of European integration usually do not consider religion to be a salient factor (cf. Loth and Wessels, 2001; Spohn, 2006). On the contrary, in projecting the modernization-cum-secularization thesis of mainstream political and social scientific analysis of the nation-state society on the composite level of the transnational European regime, they presuppose, if so, an emerging secular form of European cultural integration, a secular European identity or European civil religion (critically Casanova, 2004, Siedentop, 2001: 189-214). Against this background, the recent edited volume by Timothy Byrnes and Peter Katzenstein, Religion in an Expanding Europe (2004), has demonstrated in several assembled contributions a crucial point: the positive, ambivalent, as well as negative role of the various national and transnational religious actors, particularly of Catholicism, Orthodox Christianity and Islam in select European countries for the extension of the European Union to the East. In theoretical terms, Byrnes and Katzenstein explicitly reject the mainstream secularization thesis of European integration theories and subscribe to a multiple modernities perspective that assumes the continuing relevance of organized religion in its European multiple forms.

As path-breaking as this collective analysis of the role of religion in European integration and enlargement is, however, the multiple modernities approach used here does not go far enough. From my own perspective, following more strictly Shmuel Eisenstadt's comparative-civilizational framework (Spohn, 2001), European multiple modernity should not be restricted, as the Byrnes and Katzenstein volume does, to the continuing salience of the religious realm in its manifold religious organizations and actors alone but also considered in its constitutive institutional and cultural role for the secular realm of politics, states, nations and collective identities and, accordingly, the transnational EU regime and an emergent European identity. In all brevity, I would like to address here four main pillars of my multiple modernities approach to Europeanization, religion and secularization.

First, from a comparative civilizational view, European civilization is characterized by a specific form of structural and cultural pluralism constituted by multiple political, socio-economic, religious and cultural centers as well as diverse religious and cultural life-worlds and world-views (Eisenstadt, 1987). Of particular importance, here, were the Greek and Roman institutional, legal and philosophical legacies as well as Western and Eastern Christianity in its Jewish roots and its exchange with and opposition to Islam. On these manifold institutional and cultural foundations, Europe was not formed as a fixed social entity but rather constructed and reconstructed as a developing social space with changing boundaries and identities. At its core, Europe became historically constituted through the Carolingian Empire and Latin Christianity but, at the same time, on the bases of its multiple institutional, cultural and religious sources as well as its geo-political, inter-civilizational and inter-religious relationships and conflicts it has developed with changing identity and boundary constructions (Delanty, 1995; Malmborg and Strath, 2002). The most important historical long-term 
meanings of Europe were connected to the changing relations between Western Christianity, Eastern Christianity and Islam; the cultural change of Western Christianity through the Protestant Reformation and the Enlightenment; the process of secularization and related oppositions between church and state, clericalism and anti-clericalism or religion and secularism; as well as the geopolitical attempts to unify Europe either in totalistic or pluralist forms.

Second, against the background of the multiple religious roots of European civilization, European secularization should not be viewed as a progressive, even if uneven, development from the many religious traditions to secular modernity in the form of structural differentiation between the religious and secular spheres, an encompassing expansion of the secular and the privatization of religion. Rather, European secularization should be seen as a secularizing transformation of the structural and cultural pluralism of European civilization without dissolving its manifold religious sources and components (Casanova, 1994; Davie, 2000; Eder, 2003; Martin, 1978; 2005). Structural differentiation between state and church, the development of a secular culture and the privatization of religion do not represent comprehensive processes but have been developing in specific configurations depending on their religious foundations, specific cultural forms and secularization patterns. As well, these secularization processes have often been accompanied by the sacralization of the secular sphere, particularly in the form of secular or political religions, secular or political ideologies and secularist or quasi-religious collective identities, be it the state, the nation or the people and related forms of collective identification (Eisenstadt, 2000; 2003). In other words, within the framework of European multiple modernity, national and European collective identities are not simply secular or post-secular but consist of multiple religious as well as secular components (Martin, 2005).

Third, based on the foundations of European multiple modernity, the different forms of religious development and secularization patterns in the context of inter-civilizational encounters and conflicts were accompanied by important changes in the construction of European identities and boundaries. In the Middle Ages, the continuing expansion of Islam at the cost of Eastern Christianity laid the ground for the connection between Western Christianity and Europe. The Protestant Reformation and the Catholic Counter-Reformation introduced a basic religious cleavage into Western Christianity but also led to the Treaty of Westphalia which attempted to balance national conflicts and contain religious cleavages. The simultaneous Western expansion of the Ottoman Empire into Orthodox Eastern Europe sharpened the oppositions between Latin Christianity and Islam but at the same time weakened the religious cleavages between Western and Eastern Christianity. The Enlightenment, the French Revolution and the following secularist revolutions in Europe further bridged the CatholicProtestant divide in Western Christianity, but at the same time sharpened the opposition between the enlightened-modern Occident and despotic-backward religious Orient. In the aftermath of the two world wars, the expanding secularisttotalitarian revolutions in the East contributed also to a bridging of the confessional and religious-secularist divide in Western Christianity. 
Fourth, the post-war division of Europe in 1945 enabled the developing unification of Western Europe on the basis of Latin Christianity and strongly secularizing societies in confrontation with communist-atheistic Eastern Europe in the context of the global East-West conflict. This European constellation contributed to the pacification of the conflictive potential of religion on both sides of the Iron Curtain. In post-1989 Europe, however, the restoration of the structural and cultural pluralism of European civilization has been accompanied by the expansion of the Western European secular integration project to the East. This enlarging process of Europeanization has been confronted with growing opposition and tensions between the Western European secular-cultural integration mode and the Eastern European revival of nationalism and religion. In addition, the contemporary wave of globalization with growing immigration and intensifying inter-civilizational interactions has contributed to increasing tensions between secularized Latin Christian Europe, revived Christian Orthodox Europe and the Islamic civilization (Axtmann, 1999; Delanty, 2005). These culturalreligious asymmetries are at the core of the conflictive dynamics of the enlarging European integration to the East and South-East.

\section{European Multiple Modernity, Religion and European Cultural Integration}

The first major reason for the growing importance of religion in European integration and the related European cultural integration mode was the restoration of the encompassing structural and cultural pluralism and with it the religious diversity of Europe. European integration was first and foremost based on the formation of transnational economic, political and legal institutions and policies, whereas the issue of European cultural integration and the emergence of a European identity remained, for a long while, rather silent or latent (Kohli, 2002; Shore, 2000). The original political bases of European integration were Catholic, Catholic-laicist and mixed Catholic-Protestant countries, as well as social Catholic and Christian Democratic politicians and intellectuals, yet when the issue of a European identity as a response to the emerging European legitimacy deficit emerged, it was framed primarily in secular politico-legal and socio-economic rather than cultural and religious terms. This changed only with the confrontation of the Western European-based EU by the new member states in the East, their different forms of religion, lower cultural secularization and strong currents of religious nationalism, as well as the contentious issue of the potential incorporation of Turkey with a state-secularist regime but rising mobilization of Islam. However, the attempt to explicitly articulate the European cultural integration model by formulating an overarching canopy of the manifold, religious, spiritual, cultural and secular sources of European identity in the preamble of constitutional treaty revealed the difficulties of transposing the humanist-secularist and Western Christian-based cultural integration mode to the Eastern European new member states and candidates with their differing Catholic, Orthodox Christian and Islamic legacies. 
The European cultural integration mode, including the form of religious governance, has been emerging as an institutional and legal framework to come to terms with originally Western European religious and secular diversity. As a corollary to the multi-level regime of the European Union, it formulates, on the one hand, at the European level, the general principles of human rights, cultural and religious rights in parallel to the national constitutions of each individual member state and, on the other, leaves it to the individual nation-states to enact those principles according to their own legal, cultural and religious traditions. At the European level, the basic principles encompass in particular the values of religious freedom, EU neutrality against different world-views, tolerance towards different religious and secular orientations as well as equal treatment of religious communities. At their core, these principles are motivated by a humanist-secular and religious-ecumenical value system that attempts to overcome the clericalanti-clerical or religious-secularist cleavages so characteristic of most European trajectories of secularization. At the multiple national levels, the legal, cultural and religious traditions are principally respected. Accordingly, there is a wide legal-institutional national space for national forms of religious governance: specific relationships between state and church(es); between church(es) and other religious communities, as well as between the religious and secular spheres (Koenig, 2006).

The institutional and cultural foundations of this European cultural and religious integration derive from the converging trends in state-church relations in the context of religious development and secularization in the originally Western European member states of the European Community. In institutional terms, there are three types of state-church relations: (1) the strict separation of state and church; (2) cooperation between state and church; and (3) the preservation of a state-church (Robbers, 1995). These three types are embedded in the historically differing secularization patterns of Catholic, Protestant-Catholic mixed, and Protestant countries (Martin, 1978; 2005; Spohn, 2003). First, the tendency towards the separation of state and church is most characteristic of Catholic countries with a strong anti-clerical-secularist reaction against the traditionally strong bond between the ancien régime and the Catholic Church. An institutional strict separation between state and church, however, materialized only as an outcome of the French Revolution in laicistic-republican France, whereas in most other Western Catholic countries the clerical/anti-clerical conflicts, as in Italy, Spain, Portugal and Austria, were overcome by rather cooperative links between state and church. Second, the same is true for confessionally mixed countries, such as Germany, the Netherlands, Belgium and Switzerland, where the conflicts between Catholicism and Protestantism as well as between established state churches and anti-clerical secularism in the end resulted in cooperative relations between the state and the churches. Third, state church traditions remain characteristic of Protestant countries such as Great Britain or Scandinavia, though limited by Protestant pluralism and also by different degrees of disestablishment. Despite these rather different historical traditions in state-church relations, however, there are converging tendencies through cultural secularization, the reduced importance of churches and religion, the decline of clerical/anti-clerical 
or religious/secularist conflicts and an ecumenical rapprochement between the various religions as well as state loyalty and state support of churches and religious communities. These converging tendencies also define the core of the cultural integration mode and religious governance of the European Union.

This European canopy of cultural integration and religious governance, however, reveals its Western European, Latin Christian and secular-humanist bases when now confronted, in the context of the Eastern enlargement of the European Union, with the different and diverging religious trajectories and secularization patterns and their impacts on collective identities in the new Eastern member states and candidates (Pollack, 1998; Spohn, 1998; 2003). In particular, these are East-Central European Catholicism, South-East European Orthodox Christianity as well as South-East European and Near Eastern Islam. In all these Eastern countries, despite their differences, the secularization patterns are generally characterized by limited secularization and a strong revival of religion as well as related strong bonds between religion and national identity. In East-Central European Catholicism - the most conspicuous case here is Poland - the institutional separation between state and church is characteristic, but at the same time, due to the development of the close organic relation to national identity during the communist times, typically the Catholic Church has had a strong influence on national politics and national identity, privileging its role in society over other religions and world-views and thus contradicting the European Union principles of state neutrality, tolerance and egalitarian status. In South-Eastern European Christian Orthodox countries, there has historically been an even closer caesaropapist link between state and church and, in addition, due to their peripheral position vis-à-vis Western and Eastern empires, a strong bond with an organic form of nationalism - both privileging Christian Orthodoxy in post-communist times against other forms of religion and world-views. And, finally, in Turkey, as the most important non-Christian Islamic candidate, the Kemalist Revolution removed Islam as the traditional religious core institution of the Ottoman Empire and established, following the French model, a secularist state regulating privatized Islam, but at the same time, Turkey now is faced with the rising mobilization of Islamic social movements and political parties against the authoritarian secularist state (Yavuz, 2004; Zürcher, 2004).

As a result, the multi-level mode of cultural integration and religious governance is confronted, in the context of the restored encompassing structural and cultural pluralism of European civilization and the eastern enlargement of the European Union, with a crucial religious and cultural asymmetry. The original Western European cultural integration mode, based on Western European, Latin Christianity and highly secularized societies is in marked tension with the more religious and less secularized East European societies and their forms of cultural integration and religious governance. The EU politics of eastern enlargement has to some extent successfully imposed some of the basic Western European standards of religious freedom, neutrality of the state and religious/secular equality. As well, the privileged status of the respective Christian churches in most post-communist countries has triggered a stronger cultural secularization 
process. Both tendencies seem to signal a converging movement towards the Western European model of cultural integration and religious governance. At the same time, however, the multi-level model of European cultural integration allows the continuation and preservation of national forms of cultural and religious integration in East-Central European member states that conversely could have a narrowing effect on the humanist-secular and Latin-Christian European cultural integration model. And in addition, regarding the accession negotiations with Turkey, this development could weaken the European secular-humanist bridge to the Turkish state-secularist regime and strengthen the European Christian core against the tendencies of Islamic mobilization and pluralization.

\section{Europeanization, Ethnic Minorities and Religious Diversity}

The second major factor in the growing role of religion in European integration consists of the transformation of the historical composition of the structural and cultural pluralism of European civilization through the increasing impact of international migration and immigration on European societies (Spohn and Triandafyllidou, 2003). As a consequence, the numbers of immigrant ethnic minorities with different religious and civilizational backgrounds have increased considerably and have contributed to a marked transformation of the ethnic composition of European societies and thus a considerable diversification of religion in Europe. Of particular importance here are the growing number of Muslims from Islamic countries (Esposito and Burgat, 2003; Madood and Werbner, 1996; Shadid and Koningsveld, 2001), but also members of other world religions such as Buddhism and Hinduism in addition to the growing numbers of adherents to new religions and Protestant evangelical sects (Madeley and Zsolt, 2003; Shadid and Koningsveld, 2002). In parallel with the European immigration patterns between Western European core countries and Southern and Eastern European semi-peripheries, which until 1989 were markedly uneven, also the diversification of religion was first and foremost a phenomenon of Western and Northern European societies. But after the fall of communism, with growing immigration also to Southern and East-Central European countries, religious diversification represents a growing tendency in all European societies. As a consequence, also the modes of cultural integration and forms of religious governance at the national as well as the European level are facing an increasingly changing religious situation.

The modes of cultural integration of non-Christian forms of religion in European societies are closely linked to two institutions: the varying national regimes of religious governance as well as national incorporation modes of immigrants and related forms of citizenship. Through the process of Europeanization, these varying national institutional frameworks are at the same time influenced by the emerging forms of European religious governance, European immigration policy and European citizenship (Koenig 2006). Regarding first of all the national forms of religious governance - primarily a product of managing the religious/secularist 
cleavage and conflicts between the predominant Christian religious and the secular nation-state (Koenig, 2004) - they are now increasingly confronted with growing religious diversification, particularly in the form of Islam. The general institutional tendency is to include other religions in the main legal-moral principles of national religious governance, i.e., religious freedom, religious tolerance, state neutrality and legal equality. At the same time, however, acceptance of nonChristian religions as equal to Christian ones in European societies is in practice still severely limited (Koenig, 2006; Shadid and Koningsveld, 2002). On the one hand, the tendency towards the materialization of religious freedom, tolerance and equality is supported by the European cultural integration mode and related European religious governance. On the other, as a multi-level regime, however, it acknowledges on the basis of subsidiarity the primacy of the national frameworks of religious governance and thus intervenes at the national level only in exceptional cases.

Second, the modes of cultural integration of non-Christian religions are primarily linked to the varying national incorporation modes of immigrants and related citizenship regimes for immigrant ethnic minorities and only secondarily to an emerging form of European citizenship (Koenig, 2006). At the varying national levels and with marked West-East European unevenness, at present, two general tendencies are at work. On the one hand, there has developed a policy to strongly restrict the overall number of immigrants and integrate the existing immigrant population into the existing forms of civil, political and social citizenship. This predominant Marshallian model of citizenship, however, abstracts from the different cultural and religious traditions and lifeworlds of immigrants and thus is based on a secular notion of incorporation (Kymlicka, 1995). On the other hand, the growing presence and public articulation of minority religions, particularly of Islam, have increasingly challenged this secular cultural integration mode, and as a reaction have generated modes of cultural integration including also the status of minority religions. The general direction, here, is to grant the minority religions the same rights as those of the Christian majority religions but at the same time to impose the predominant institutional relations between the nation-state and majority churches also on the minority religions. The vaguely emerging components of European citizenship (Eder and Giesen, 2002; Soysal, 1994) are based on these converging aspects of national citizenship and cultural integration modes without interfering with national immigration and citizenship policies. Within these limits, however, European citizenship attempts to strengthen minorities' rights against particularistic nationalist traditions in the member states and thus also support the cultural and religious rights of minorities against the predominant secular-religious regime at the national level.

In the context of the enlarging European Union to the East, it has become obvious that the European multi-level cultural integration mode regarding the integration of minority religions faces problems not only in Western European countries but even more so in the East-Central and South Eastern European new member states and candidates that have different types of religious governance and citizenship regimes (Kymlicka and Opalski, 2001). In Western Europe, as 
the original core of the European cultural integration model, three major types of national citizenship regimes can be distinguished, linked to the predominant type of religion and religious governance (Koenig, 2004). First, Protestant countries with differing degrees of state-church establishment and religious pluralism prioritize forms of multi-cultural citizenship, as in Great Britain and the Scandinavian countries. Second, Catholic countries with differing degrees of statechurch separation combine state-church cooperation with the preferential position of the majority Catholic Church vis-à-vis other religions and a hierarchical form of citizenship, as in most Roman-Latin countries. Third, mixed countries with a duality of Catholic and Protestant churches are characterized by forms of corporatist-hierarchical citizenship and other religions as in the Netherlands, Switzerland, and Germany. In all these cases, there are still tensions and conflicts between the European mode of cultural integration and religious governance and the widespread hierarchical-discriminatory relations between majority and minority religions at the national level.

In Eastern Europe, by contrast, the types of citizenship regimes and religious governance are still marked by the long-term peripheral dependence and imperial domination and, accordingly, the tensions and conflicts between the European and national modes of cultural integration and religious governance are much more intense. The widespread historical legacies are the intimate post-communist connection between predominant religion and majority nationalism and the close cooperation and link between state and majority church, combined with the discrimination of historical minorities and preferential treatment of the predominant church against ethnic minorities and minority religions (Spohn, 2003). On this historical basis, the rapid new influx of immigrant ethnic minorities has been met with widespread fear of national disintegration and religious estrangement. Accordingly, the tensions and conflicts with European cultural integration and religious governance exported through the eastern enlargement have been rather high. On the one hand, the EU, through the mechanism of accession negotiations, has tried to weaken the traditional conflicts of ethnic-national relations and support the institutionalization of citizenship regimes for the growing immigration populations. On the other, it has accepted the many Eastern European national regimes of citizenship and religious governance. Here, regarding the dominant religion, four main types can be distinguished. The few Protestant Baltic countries have incorporated with hesitation and limitations the (former imperial) Russian and mostly Orthodox ethnic minority. The numerous Catholic countries are now moving, though slowly and reluctantly, to a less discriminatory treatment of ethnic minorities and minority religions. The few Christian Orthodox countries with stronger links between state, majority nation and Orthodox religion are even more hesitant in this regard. And also in Turkey, the secular regime, with state-church separation and privatization of religion, goes hand in hand with privileging majority nationalism and Sunni Islam and discriminating against ethnic minorities, as well as granting preferential treatment to Islam against other minority religions. 


\section{European Enlargement, Religion and Civilizational Boundaries}

The third major reason for the growing role of religion in changing the structural and cultural pluralism of the European civilization is the current eastern enlargement of the European Union (Eder and Spohn, 2005; Mair and Zielonka, 2002; Zielonka, 2001). Emerging after the collapse of communism with the aim of unifying the whole of Europe by incorporating the Eastern European postcommunist countries, and with it finalizing the territorial-political gestalt of the European Union, it has raised controversial issues about the definition of Europe, European identity and related boundary constructions of Europe. These controversial issues concentrate on the question of the relationship between the boundaries of the European civilization and the European integration project. It is possible to define, on the basis of the historical, cultural and institutional foundations of Europe, a geographically circumscribed European culture area that basically defines the boundaries of any politically legitimate European integration framework. However, this is dependent on contemporary geo-political power relations between the European Union member states, European non-members and other nation-states in adjacent civilizations. Both the cultural and geopolitical dimensions determine whether or not and to what extent the congruency between European civilization as a European geographical culture area and the European integration project as a specific transnational political, legal and economic institutional framework will be reached. So, for instance, Russia, although it belongs to the culturally defined 'House of Europe' is not considered, due to its primary Eurasian civilizational construction, a potential member of the European Union, whereas Turkey, belonging to the non-European Islamic civilization, due to its secular European self-definition, is regarded at least in principle as a legitimate future member state. In other words, the enlargement of Europeanization to the East depends, on the historical and cultural basis of European civilization, on contemporary civilizational self-definitions, as well as intra- and inter-civilizational boundary constructions (Delanty, 2005).

In this civilizational and inter-civilizational context, the actual process of eastern enlargement of the EU has materialized in the accession of eight East-Central and two Southern European countries, currently including also Bulgaria and Romania, and foresees the incorporation of some further Balkan states, whereas the inclusion of Turkey, although a candidate, has been increasingly contested since the failure of the referenda on the European constitutional contract (Beichelt, 2004). The emerging alternative is an associated neighborhood status that includes special preferences and rights but not full membership and corresponding duties. This associated neighborhood status is envisioned for most Eastern European non-member states such as Ukraine and the Caucasus, but it may also apply to Turkey if the accession negotiations eventually fail (Verheugen, 2005). Given this scenario at present, it is very likely that the eastern and south-eastern enlargement of the European Union will encompass only parts of the broader defined European civilization.

The reasons for this narrower definition of an enlarged Europe as compared to the boundaries of European civilization are political-economic and legal- 
administrative as well as cultural and religious. The European Union and its representatives in managing and negotiating eastern enlargement within the framework of the Copenhagen criteria have primarily emphasized political, legal, economic and administrative reasons for negotiating and accepting EU membership. Successful accession depended primarily on the fourfold guarantees of a stable democratic polity including protection of minorities, a functioning market economy, the administrative implementation capacity as well as the ability to fulfill the obligation of the acquis communautaire. In addition, eastern enlargement also demands the adjustment of the EU institutions to the considerably enlarged number of members - a condition that has not yet materialized due to the failure to ratify the proposed European constitutional treaty but this will soon be put on the table again in a less controversial form. All these criteria are prima facie secular ones, but underneath, as I tried to demonstrate, cultural as well as religious criteria in the definition of Europe, its boundaries and the cultural legitimacy of inclusion are at work as well. Thus, it cannot be ignored that eastern enlargement has focused primarily on East-Central European countries within the orbit of Latin Christianity, extended to a limited degree, in addition to Greece, to some Orthodox countries, whereas the inclusion of Turkey has recently become more contested. This reveals that the historical core definition of Europe as a LatinChristian civilization still matters, that its relationship to Eastern Christianity is still problematic and that the oppositional-conflictive relationship to the Islamic civilization gains a new salience (Byrnes, 2001; Byrnes and Katzenstein, 2004; Siedentop, 2001).

In sum, in the expansion of the transnational European regime and its cultural integration model to the Eastern space of European civilization, in the context of contemporary intensifying globalization processes, the reconstruction of particularly three intra- and inter-civilizational cleavages are at work. First, under growing pressure to define a European identity not only in secular but also in cultural terms, and with it to give the European cultural integration mode a moral and institutional gestalt, two religious-cultural cleavages within Western Latin Christianity are losing ground. On the one hand, the tendency to bridge the confessional divide between Catholicism and Protestantism has become stronger. On both sides, at the transnational as well as national levels, there are increasing attempts to overcome or relativize the traditional theological, symbolic and ritualized differences between the two confessions. On the other, there is a strong tendency to overcome or relativize also the clerical/anti-clerical or secularist/religious divide. Both forms of Western European cultural integration contest but also have a transformative effect, in the context of eastern enlargement, on the East-Central European parts of Latin Christianity.

Second, the parallel bridging of the rift between Western and Eastern Christianity in the context of eastern enlargement, however, is much more ambivalent. The traditional feelings of cultural superiority of Latin Christianity, enhanced by the European Enlightenment, are still at work. In modern times, Orthodox Christianity had historically been viewed not only as a deviating and inferior but also as a less enlightened and more authoritarian creed (Neumann, 1999; Wolf, 1994). This image was renewed in communist times, emphasizing the accommodating 
arrangements between the communist-secularist regimes and the Orthodox Churches in contrast to the Western Christian and particularly Catholic resistance to communist rule. In the post-communist present, Eastern Europe is seen as a widely secularized space inviting renewed Catholic and Protestant reChristianization efforts. Conversely, the Orthodox Churches attempted, though only partially successfully, to re-establish themselves as state churches in the caesaro-papist tradition and restrict the missionary attempts of Catholicism and Protestant evangelicalism. Accordingly, eastern enlargement is widely seen as an imperialist expansion of Latin Christianity and Western secularism. At the same time, however, in tune with the expansion of the European cultural integration mode there are also some attempts to bridge the traditional divide in Western Christianity as well as the still virulent rift between post-communist secularism and the revival of religion in more cooperative-ecumenical ways.

Third, the combined effect of both the strong ecumenical rapprochement between Catholicism and Protestantism as well as Christianity and the secular state, and the weaker und more ambivalent one between Western and Eastern Christianity, is that the inter-civilizational cleavage between Christianity and Islam is increasing and crystallizing in a growing ambiguity to include Turkey in the European Union (Yavuz, 2004; Zürcher and von den Linden, 2004). On the one hand, the more cooperative-ecumenical attitudes between the Western Christian churches and the state and the growing conflicts with political Islam and the claims of immigrant Muslims are also supporting a stronger sentiment against the inclusion of Turkey, seen as a secular-authoritarian state under siege by a mobilizing Islam. On the other hand, the revival of Eastern Christianity and its impact on revitalized forms of religious nationalism in post-communist Eastern Europe also strengthen the traditional anti-Islamic and anti-Turkish attitudes. Conversely, also in Turkey, the pro-European, pro-accession orientations in its secularist as well as religious-reformist parts are increasingly being challenged by nationalistic, Islamic and fundamentalist currents, groups and parties.

\section{Conclusion}

In post-1989 Europe, there are three interrelated dimensions in which the revitalization of religion in the contemporary globalization phase is challenging the institutionalized European mode of cultural integration and religious governance and its expansion towards the East and South-East. First, eastern enlargement of the European Union in bridging the East-West divide of the European civilization has included and is confronted with differing types of religion and secularization, state-church relations, religious governance and cultural integration as well as political cultures and collective identities. Second, the growing impact of immigrants with different religious backgrounds, particularly but not only from Islamic countries, is transforming European societies in a more multi-cultural and pluri-religious direction. Third, globalization in its various economic, political and cultural forms is intensifying the interactions between civilizations and 
religions, enhancing the intra- and inter-civilizational boundary constructions within and beyond European civilization and thus is impinging on the conflictive dynamics of EU eastern enlargement.

On a cultural integration continuum from more inclusive to more exclusive policy strategies, there are two principal ways to respond to these threefold challenges. On the one hand, a more exclusive strategy tends to strengthen the cultural-secularist integration mode. Here, European cultural integration and collective identity are primarily centered on the received secular-humanist core by limiting religious diversity vis-à-vis immigrants and Turkey. This strategy can combine with a stronger emphasis on the Western Christian core of Europe and its ecumenical extension to Eastern Christian countries. On the other, a more inclusive strategy would attempt to strengthen the multi-religious and crosscivilizational ecumenical bases of the European cultural integration model. Here, a conscious effort would be made to encourage forms of multi-cultural citizenship and religious pluralism inside European societies and, as a corollary, to include Turkey as a crucial multi-religious and multi-cultural pillar of European cultural integration and collective identity.

The first more exclusive path is currently the main tendency. Yet, at a cost: stronger exclusion of Muslim immigrants inside European societies and their potentially growing tendency towards a fundamentalist mobilization. The second more inclusive path seems to be rather utopian or romantic and currently unrealistic. However, even if the present EU realpolitik were to result in reducing Turkey to the status of a 'privileged partner', the more inclusive strategy would strengthen the more pluralistic integration of Muslim populations in European societies and, at the same time, contribute to stronger tolerance and pluralization in Turkish politics and society, both with respect to its ethnic and religious minorities as well as with potential repercussions on the religious and political conflict zones in the Near East and Northern Africa. This cosmopolitan perspective on Europe and European integration, however, cannot be formulated in secularist terms but would have to develop a secular and ecumenical framework of religious pluralism (Beck and Grande, 2004; Casanova, 2004; Meyer, 2004).

\section{References}

Axtmann, Roland, ed. (1999) Globalization and Europe: Theoretical and Empirical Investigations. London: Pinter.

Beck, Ulrich and Grande, Edgar (2004) Das kosmopolitische Europa. Frankfurt am Main: Suhrkamp.

Beichelt, Timm (2004) Die EU nach der Osterweiterung. Mainz: utb.

Byrnes, Timothy (2001) Transnational Catholicism in Postcommunist Europe. Lanham, MD: Rowman \& Littlefield.

Byrnes, Timothy and Katzenstein, Peter, eds (2004) Religion in an Expanding Europe. Cambridge, MA: Cambridge University Press.

Casanova, José (1994) Public Religions in the Modern World. Chicago: University of Chicago Press. 
(2004) 'Religion, European Secular Identities, and European Integration', in

T. Byrnes and P. Katzenstein (eds), Religion in an Expanding Europe, pp. 65-92. Cambridge: Cambridge University Press.

Davie, Grace (2000) Religion in Modern Europe. Oxford: Oxford University Press.

Delanty, Gerard (1995) The Invention of Europe. London: Routledge.

- (2005) Rethinking Europeanization. London: Routledge.

Eder, Klaus (2003) 'Europäische Säkularisierung - ein Sonderweg in die post-säkulare Gesellschaft', Berliner Journal für Soziologie H3: 331-43.

Eder, Klaus and Giesen, Bernhard, eds (2002) European Citizenship. Oxford: Oxford University Press.

Eder, Klaus and Spohn, Willfried (2005) European Identity and Collective Memory: The Cultural Effects on European Integration and Enlargement. Aldershot: Ashgate.

Eisenstadt, Shmuel (1987) European Civilization in Comparative Perspective. Oslo: Scandinavian University Press.

— (2000) Vielfalt der Moderne. Weilerswist: Velbrück Wissenschaft.

- (2003) Multiple Modernities and Comparative Civilizations, 2 vols. Leiden: Brill.

Esposito, John and Burgat, François (2003) Modernization of Islam: Religion and the Public Sphere in Europe and the Middle East. New Brunswick, NJ: Rutgers University Press.

Giesen, Bernhard and Suber, David, eds (2004) Religion and Politics: Cultural Perspectives. Leiden: Brill.

Ichijo, Atsuko and Spohn, Willfried, eds (2005) Entangled Identities: Europe and the Nation. Aldershot: Ashgate.

Jachtenfuchs, Markus and Kohler-Koch, Beate (1996) Europäische Integration. Opladen: Leske + Buderich.

Koenig, Matthias (2003) Staatsbürgerschaft und religiöse Pluralität in post-nationalen Konstellationen. Zum institutionellen Wandel europäischer Religionspolitik am Beispiel muslimischer Immigranten in Großbritannien, Frankreich und Europa. Marburg: Diss.

_ (2004) 'Politics and Religion in European Nation-States: Institutional Varieties and Contemporary Transformations', in B. Giesen and D. Suber (eds) Religion and Politics: Cultural Perspectives, pp. 291-316. Leiden: Brill.

- (2006) 'Europeanizing the Governance of Religious Diversity: An Institutionalist Account of Muslim Struggles for Public Recognition', Journal of Ethnic and Migration Studies 33(6): 911-32.

Kohli, Martin (2000) 'The Battlegrounds of European Identity', European Societies 2(2): 113-37.

Kymlicka, Will (1995) Multi-cultural Citizenship: A Liberal Theory of Minority Rights. Oxford: Clarendon Press.

Kymlicka, Will and Opalski, Magda, eds (2001) Can Liberalism Be Exported? Western Political Theory and Ethnic Relations in Eastern Europe. Oxford: Oxford University Press.

Loth, Wilfried and Wessels, Wolfgang, eds (2001) Theorien europäischer Integration. Opladen: Leske + Buderich.

Madeley, John and Enyedi, Zsolt, eds. (2003) Church and State in Contemporary Europe: The Chimera of Neutrality. London: Frank Cass.

Madood, Tariq and Werbner, Pnina, eds (1996) The Politics of Multiculturalism in the New Europe. London: Zed.

Mair, Peter and Zielonka, Jan, eds (2002) The Enlarged European Union: Diversity and Adaptation. London: Frank Cass.

Malmborg, Mikael and Stråth, Bo, eds (2002) The Meaning of Europe. Oxford: Berg.

Martin, David (1978) A General Theory of Secularization. Oxford: Blackwell. 
— (2005) Secularization: Towards a Revised Theory. Aldershot: Ashgate.

Meyer, Thomas (2004) Die Identität Europas. Frankfurt am Main: Suhrkamp.

Minkenberg, Michael and Willems, Ullrich, eds (2003) Politik und Religion. Sonderheft Politische Vierteljahresschrift 33, Wiesbaden: Westdeutscher Verlag.

Neumann, Iver (1999) The Uses of the Other: The 'East' in European Identity Formation. Minneapolis: University of Minnesota Press.

Pollack, Detlef, et al., eds (1998) Religiöser Wandel in den post-kommunistischen Ländern Ost- und Mitteleuropas. Würzburg: Ergon.

Robbers, Gerhard, ed. (1995) Staat und Kirche in der Europäischen Union. Baden-Baden: Nomos.

Shadid, W.A.R. and von Koningsveld, P., eds (2001) Religious Freedom and the Neutrality of the State: The Position of Islam in the European Union. Leuven: Peters.

- eds (2002) Intercultural Relations and Religious Authorities: Muslims in the European Union. Leuven: Peters.

Shore, Cris (2000) Building Europe: The Cultural Politics of European Integration. London: Routledge.

Siedentop, Larry (2001) Democracy in Europe. London: Penguin.

Soysal, Yasemine (1994) Limits of Citizenship: Migrants and Postnational Membership in Europe. Chicago: University of Chicago Press.

Spohn, Willfried (1998) 'Religion und Nationalismus. Osteuropa im westeuropäischen Vergleich', in D. Pollack et al. (eds) Religiöser Wandel in den post-kommunistischen Ländern Ost- und Mitteleuropas, pp. 87-120. Würzburg: Ergon.

_ (2001) 'Eisenstadt on Civilizations and Multiple Modernities', European Journal of Social Theory 4(4): 499-508.

— (2003) 'Nationalismus und Religion. Ein historisch-soziologischer Vergleich Westund Osteuropas', in M. Minkenberg and U. Willems (eds) Politik und Religion. Sonderheft Politische Vierteljahresschrift 33, pp. 323-45. Wiesbaden: Westdeutscher Verlag. - (2006) 'Interdisziplinäre Europastudien: der Ansatz multipler Modernitäten', in

T. Beichelt et al. (eds) Interdisziplinäre Europastudien. Eine Einführung, pp. 435-51. Wiesbaden: Verlag Sozialwissenschaften.

Spohn, Willfried and Triandafyllidou, Anna, eds (2003) Europeanization, National Identities and Migration: Changes in Boundary Construction between Western and Eastern Europe. London: Routledge.

Verheugen, Günter (2005) Europa in der Krise. Cologne: Kiepenheurer \& Witsch.

Wolf, Larry (1994) The Enlightenment and the Orthodox World: Western Perspectives on the Orthodox Church in Eastern Europe. Athens: Institute for Neohellenic Research.

Yavuz, Hakan (2003) Islamic Political Identity in Turkey. Oxford: Oxford University Press. Zielonka, Jan, ed. (2001) Europe Unbound. London: Routledge.

Zürcher, Erik (2004) Turkey: A Modern History. New York: Tauris.

Zürcher, Erik and von den Linden, H., eds (2004) The European Union, Turkey and Islam. Amsterdam: Amsterdam University Press.

Willfried Spohn is adjunct professor in sociology at the Free University of Berlin and currently director and coordinator of a research project 'Europeanization, multiple modernities and collective identities - religion, nation and ethnicity in an enlarged Europe', funded by the Volkswagen Foundation at the University of Goettingen, 2008-11. He specializes in historical and comparative sociology, multiple modernities and globalization with a research focus on politics and 
religion in Europe in a civilizational-comparative perspective. His recent publications include 'History and the Social Sciences', in International Encyclopedia of the Social Sciences (2001); 'Nationalismus und Religion. Ein historisch-soziologischer Vergleich West- und Osteuropas', Politische Vierteljahresschrift (2003); 'Multiple modernity, nationalism and religion - a global perspective', Current Sociology (2003); 'Globale, multiple und verwobene Moderne - Perspektiven der historischvergleichenden Soziologie', in Th. Schwinn (ed.), Vielfalt und Einheit der Moderne (2006); and Politics and Religion in a Globalizing World (2008); as well as edited volumes (with Anna Triandafyllidou), Europeanization, National Identities and Migration (Routledge, 2002); (with Atsuko Ichijo) Entangled Identities: Europe and the Nation (Ashgate, 2005); and (with Klaus Eder), Collective Memory and European Identity: Effects of Integration and Enlargement (Ashgate, 2005). His current book project is Historical-Comparative Sociology in a Globalizing World: Theoretical Approaches, Empirical Investigations and Research Perspectives. He has taught at several German and US universities and is currently president of the ISA Thematic Group 'Historical and Comparative Sociology'. Address: Department of Sociology, Free University of Berlin, Berlin, Germany. [email: willfried.spohn@ uni-goettingen.de] 